\title{
Peningkatan Hasil Pembelajaran HOTs pada Mata Pelajaran Bahasa Inggris Materi Expressing Giving Compliment and Congratulation Melalui Scientific Approach Model Pembelajaran Abad Ke-21 Metode Blended Learning Peserta Didik Kelas X.IPK.3 MAN 2 Kota Payakumbuh Semester Ganjil Tahun Pelajaran 2021/2022
}

\author{
Josmartin Peto \\ 1,2 MAN 2 Kota Payakumbuh \\ JL. Tj. Gadang, Kec. Payakumbuh Bar., Kota Payakumbuh, Sumatera Barat, Indonesia \\ josmartin_peto@gmail.com
}

\begin{abstract}
This study aims to see and analyze the increasing in learning outcomes of students in class X.IPK.3 Payakumbuh Odd Semester for the 2021/2022 Academic Year, in English subjects Expressing Giving Compliment and Congratulation Materials through the Scientific Approach of the 21st Century Learning Model Blended Learning Method in HOTS learning. This research was conducted using the Classroom Action Research method which consisted of two cycles, where each cycle consisted of: planning, action, reflection, and evaluation. It was conducted from August to November 2021. The data was processed in each cycle and then analyzed using percentages. The results obtained in the pre-cycle, cycle I and cycle II showed an increase. The average grade for students' knowledge increased from 49.31 with $0 \%$ completeness in the pre-cycle to 73.43 to $(41.67 \%)$ in the first cycle and $77.70(77.78 \%)$ in the second cycle. Here it can be seen that the percentage of students who did not complete decreased. The average value of the skill class was significant. It is proven by the gain from 80.56 in the pre-cycle to $84.51(4.90 \%)$ in the first cycle, and to $93.61(10.77 \%)$ in the second cycle. In each action, all students complete $100 \%$. Based on the results of the second cycle assessment, it can be interpreted that the implementation of the 21st Century Scientific Approach Learning Model Blended Learning Method can improve students' high-level English learning outcomes, although the increase is not in line with expectations, but it is quite effective in learning English. The conclusion obtained from this research is that the use of the Scientific Approach 21st Century learning model with the Blended Learning method in HOTS learning can improve student learning outcomes.
\end{abstract}

Keywords: HOTS Learning Results, Blended Learning Model for 21st Century

\begin{abstract}
Abstrak
Penelitian ini bertujuan untuk melihat dan menganalisis peningkatan hasil belajar siswa kelas X.IPK.3 Semester Ganjil Tahun Pelajaran 2021/2022, pada mata pelajaran Bahasa Inggris Mengungkapkan Materi Pemberian Pujian dan Ucapan Selamat melalui Pendekatan Ilmiah Pembelajaran Abad 21 Model Metode Blended Learning dalam pembelajaran HOTS. Penelitian ini dilakukan dengan menggunakan metode Penelitian Tindakan Kelas yang terdiri dari dua siklus, dimana setiap siklus terdiri dari: perencanaan, tindakan, refleksi, dan evaluasi. Penelitian dilaksanakan pada bulan Agustus hingga November 2021. Data diolah dalam setiap siklus kemudian dianalisis menggunakan persentase. Hasil yang diperoleh pada pra siklus, siklus I dan siklus II menunjukkan peningkatan. Nilai rata-rata pengetahuan siswa meningkat dari 49,31 dengan ketuntasan $0 \%$ pada pra siklus menjadi 73,43 menjadi $(41,67 \%)$ pada siklus I dan $77,70(77,78 \%)$ pada siklus II. Di sini terlihat bahwa persentase siswa yang tidak tuntas mengalami penurunan. Nilai rata-rata kelas keterampilan adalah signifikan. Hal ini dibuktikan dengan peningkatan dari 80,56 pada pra siklus menjadi $84,51(4,90 \%)$ pada siklus I, dan menjadi 93,61 (10,77\%) pada siklus II. Dalam setiap tindakan, semua siswa menyelesaikan $100 \%$. Berdasarkan hasil penilaian siklus II dapat diartikan bahwa penerapan Model Pembelajaran Blended Learning Model Scientific Approach Abad 21 dapat meningkatkan hasil belajar bahasa Inggris tingkat tinggi siswa, walaupun peningkatannya tidak sesuai dengan harapan, namun cukup efektif dalam belajar bahasa inggris. Kesimpulan yang diperoleh dari penelitian ini adalah penggunaan model pembelajaran Scientific Approach Abad 21 dengan metode Blended Learning dalam pembelajaran HOTS dapat meningkatkan hasil belajar siswa.
\end{abstract}

Kata kunci: Hasil Belajar HOTS dan Model Pembelajaran Blended Learning Abad 21

Copyright (c) 2021 Josmartin Peto

Corresponding author: Josmartin Peto

Email Address: josmartin_peto@gmail.com (Jl. Tj. Gadang, Kota Payakumbuh, Sumatera Barat)

Received 10 January 2022, Accepted 20 January 2022, Published 20 January 2022 


\section{PENDAHULUAN}

Pandemi Covid-19 sangat mempengaruhi segala aspek kehidupan. Mulai dari aspek ekonomi, sosial, hankam sampai pendidikan. Kita insan pendidikan sempat kewalahan dengan kondisi pendidikan pada saat ini. Semua unsur harus melaksanakan proses belajar mengajar di rumah secara online. Media teknologi informasi merupakan hal yang paling diperlukan demi proses pendidikan berjalan dengan baik. Keterbatasan kita berinteraksi sangat mempengaruhi hasil proses belajar mengajar. Peserta didik dan tenaga pendidik hanya mengenal satu sama lain di dunia maya. Hingga saat ini, sebagian besar dunia masih mengalami masa pandemi virus corona atau Covid 19. Semua sektor kehidupan diatur sesuai dengan protokol Kesehatan termasuk sector Pendidikan. Pendidikan di Indonesia masih menggunakan pembelajaran Covid 19.

Bahasa Inggris sebagai salah satu ilmu pengetahuan yang memiliki peranan penting dalam pendidikan. Disiplin ilmu ini juga merupakan komponen penting mendasari perkembangan teknologi modern. Teknologi tidak dapat berkembang dengan baik jika mereka tidak menguasai Bahasa Inggris, baik secara tertulis maupun lisan. Dalam memecahkan suatu masalah dalam kehidupan, sering sekali kita menggunakan konsep dan pemecahan masalah matematika. Dalam aktivitas sehari-hari, kita pasti menggunakan Bahasa Inggris. Informasi dan proses dalam melaksanakan sesuatu kebanyak menggunakan bahasa Inggris. Jadi Bahasa Inggris merupakan salah satu mata pelajaran yang sangat penting dipelajari disetiap jenjang pendidikan hingga ke perguruan tinggi.

Implemetasi kegiatan pembelajaran Bahasa Inggris secara dasar cukup menyulitkan peserta didik dan guru saat pandemi Covid 19, apalagi peserta didik harus belajar dari rumah. Belajar jarak jauh di rumah berarti orang tua memiliki peran penting untuk memantau kegiatan anak di rumah selama sekolah diliburkan di masa Covid 19 ini, apalagi kalau peserta didik diajak belajara Bahasa Inggris melalui daring (dalam jaringan). Pembelajaran daring selama pandemi mengakibatkan peserta didik mengalami beberapa kesulitan dalam memahami konsep pembelajaran serta menyelesaikan soal yang diberikan oleh guru. Kemampuan peserta didik berkurang seiring motivasi peserta didik dalam belajar berkurang.

Penulis sebagai salah seorang guru mata pelajaran Bahasa Inggris di kelas X.IPK.3 MAN 2 Kota Payakumbuh pada awal Semester Ganjil Tahun Pelajaran 2021/2022 melihat adanya masalah dan fenomena dalam proses pembelajaran di masa pandemic Covid 19. Masalah atau fenomena yang ditemukan adalah masih rendahnya hasil belajar peserta didik. Hal ini dapat dilihat diantaranya dari hasil ulangan harian peserta didik pada materi pokok sebelum dilaksanakan penelitian.

Berdasarkan observasi awal bahwa di kelas X.IPK.3 MAN 2 Kota Payakumbuh memiliki nilai rata-rata paling rendah dari kelas yang lain, yaitu dengan nilai rata-rata pengetahuan 49,31 dan nilai rata-rata keterampilan 84,59 . Terlihat tidak adanya peserta didik yang tuntas pada aspek pengetahuan dan berbanding terbalik dengan aspek keterampilan.

Menyikapi kondisi tersebut di atas penulis mencoba menggunakan model pembelajaran Blended Learning. Model Pembelajaran Blended Learning mempunyai tujuan utama untuk 
Peningkatan Hasil Pembelajaran HOTs pada Mata Pelajaran Bahasa Inggris Materi Expressing Giving Compliment and Congratulation Melalui Scientific Approach Model Pembelajaran Abad Ke-21 Metode Blended Learning Peserta Didik Kelas X.IPK.3 MAN 2 Kota Payakumbuh Semester Ganjil Tahun Pelajaran 2021/2022, Josmartin Peto 387 memberikan pelatihan kepada peserta untuk lebih bisa bekerjasama yang efektif, saling memberikan informasi, serta mendengar dan menggunakan ide-ide orang lain, sesuai dengan tuntutan abad ke-21. Model pembelajaran Blended Learning adalah pembelajaran yang menggabungkan metode daring dan tatap muka. Pada pembelajaran abad ke-21, seiring dengan perkembangan IPTEK, pendidikan di abad ke-21 ini memiliki tiga karakteristik utama, yaitu: karakter, kompetensi, dan literasi. Sepuluh nilai utama karakter bangsa untuk mengembangkan karakter positif, yaitu: (1) religius, (2) jujur, (3) disiplin, (4) bekerja keras (5) mandiri, (6) demokratis, (7) rasa ingin tahu, (8) semangat kebangsaan, (9) gemar membaca, (10) peduli lingkungan. Kompetensi yang mutlak dimiliki dalam pendidikan abad 21 ini, meliputi: berpikir kritis dan pemecahan masalah (Critical Thinking and Problem Solving), komunikatif (Communication), kolaboratif (Collaboration), serta kreativitas dan inovasi (Creativity and Innovation). Literasi (keterbukaan wawasan), meliputi literasi baca, literasi budaya, literasi teknologi, dan literasi keuangan. Dalam menjawab era Revolusi Industri 4.0, tidak cukup hanya menerapkan literasi lama (membaca, menulis, berhitung), tetapi harus menerapkan literasi baru (literasi data, literasi teknologi dan literasi sumber daya manusia atau humanisme) yang memerlukan mata pelajaran matematika disetiap satuan pendidikan.

Berdasarkan latar belakang masalah diatas, maka penelitian ini bertujuan untuk mengetahui apakah penggunaan Scientific Approach Model Pembelajaran Abad ke-21 Metode Blended Learning dapat meningkatkan hasil pembelajaran tingkat tinggi (HOTS) Mata Pelajaran Bahasa Inggris Materi Expressing Giving Compliment and Congratulation KD 3.2-4.2di Kelas X.IPK.3 MAN 2 Kota Payakumbuh Semester Ganjil Tahun Pelajaran 2021/2022.

\section{METODE}

Penelitian ini adalah penelitian tindakan kelas Rancangan penelitian yang menggunakan empat langkah yaitu: Perencanaan (planning), Tindakan (action), Observasi (observation), Refleksi/evaluasi (reflection). Subjek penelitian adalah peserta didik kelas X.IPK.3 MAN 2 Kota Payakumbuh yang berjumlah 36 orang peserta didik dengan jumlah 36 siswa laki-laki. Penelitian ini dilaksanakan di MAN 2 Kota Payakumbuh di kelas X.IPK.3 Tahun Pelajaran 2021/2022 yang beralamat di Jalan Soekarno - Hatta Kelurahan Padangtongah Balai Nan Duo Koto Nan IV Payakumbuh Barat Kota Payakumbuh. Waktu penelitian dilaksanakan dari pertengahan bulan Agustus sampai akhir Oktober 2021. Penelitian Tindakan Kelas direncanakan akan dilakukan sebanyak 2 siklus. Pada siklus I dilakukan empat kali pertemuan dan siklus II dilakukan empat kali pertemuan. Instrumen penelitian terdiri dari Observasi, Tes Hasil Belajar. Teknik pengumpulan data terdiri dari Analisis Observasi. Hasil observasi dianalisis dengan metode analisis deskriptif komparatif teknik presentatif. 


\section{HASIL DAN DISKUSI}

\section{Deskripsi Prasiklus}

Tahap awal penelitian penulis mengambil hasil penilaian harian 1 peserta didik kelas X.IPK.3 MAN 2 Kota Payakumbuh semester ganjil tahun pelajaran 2021/2022 untuk nilai prasiklus yang terdiri dari nilai pengetahuan dan nilai ketrampilan. Nilai prasiklus ini menjadi acuan perencanaan tindakan selanjutnya pada siklus I.

\section{Nilai Pengetahuan}

Nilai pengetahuan prasiklus yang diambil dari Penilaian Harian 1 dapat dilihat pada lampiran. Hasil pengolahan perolehan nilai dapat dilihat pada table berikut.

Tabel 1. Hasil Pengolahan Nilai Pengetahuan Prasiklus

\begin{tabular}{|c|l|c|}
\hline No & \multicolumn{1}{|c|}{ Uraian } & Frekuensi \\
\hline 1. & Jumlah Peserta Didik & 36 \\
\hline 2. & Peserta didik yang tuntas & 0 \\
\hline 3. & Peserta didik yang tidak tuntas & 36 \\
\hline 4. & Nilai rata-rata kelas & 49,31 \\
\hline 5. & Persentase Ketuntasan & 0 \\
\hline
\end{tabular}

Berdasarkan nilai pengetahuan prasiklus pada table di atas terlihat bahwa tidak ada satu pun peserta didik yang tuntas. Hasil pengolahan nilai pengetahuan ini dapat dilihat pada gambar 1 berikut:

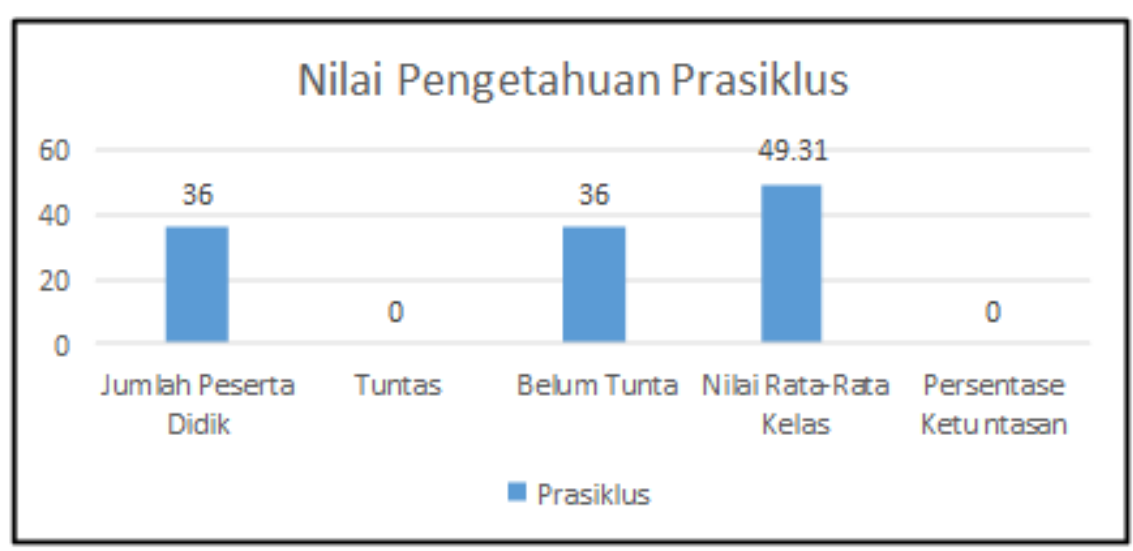

Gambar 1. Nilai Pengetahuan Prasiklus

\section{Keterampilan}

Nilai keterampilan prasiklus yang diambil dari Penilaian Harian 2 dapat dilihat pada lampiran. Hasil pengolahan nilai dapat dilihat pada table berikut.

Tabel 2. Hasil Pengolahan Nilai Keterampilan Prasiklus

\begin{tabular}{|c|l|c|}
\hline No & \multicolumn{1}{|c|}{ Uraian } & Frekuensi \\
\hline 1. & Jumlah Peserta Didik & 36 \\
\hline 2. & Peserta didik yang tuntas & 36 \\
\hline 3. & Peserta didik yang tidak tuntas & 0 \\
\hline 4. & Nilai rata-rata kelas & 80,56 \\
\hline 5. & Persentase Ketuntasan & 100 \\
\hline
\end{tabular}


Peningkatan Hasil Pembelajaran HOTs pada Mata Pelajaran Bahasa Inggris Materi Expressing Giving Compliment and Congratulation Melalui Scientific Approach Model Pembelajaran Abad Ke-21 Metode Blended Learning Peserta Didik Kelas X.IPK.3 MAN 2 Kota Payakumbuh Semester Ganjil Tahun Pelajaran 2021/2022, Josmartin Peto

Pada tabel di atas menunjukkan bahwa, dari secara keseluruhan peserta didik yang mengikuti tes tuntas. Perolehan nilai rata-rata kelas 80,56 . Hasil pengolahan nilai di atas dapat dilihat pada gambar 2 berikut:

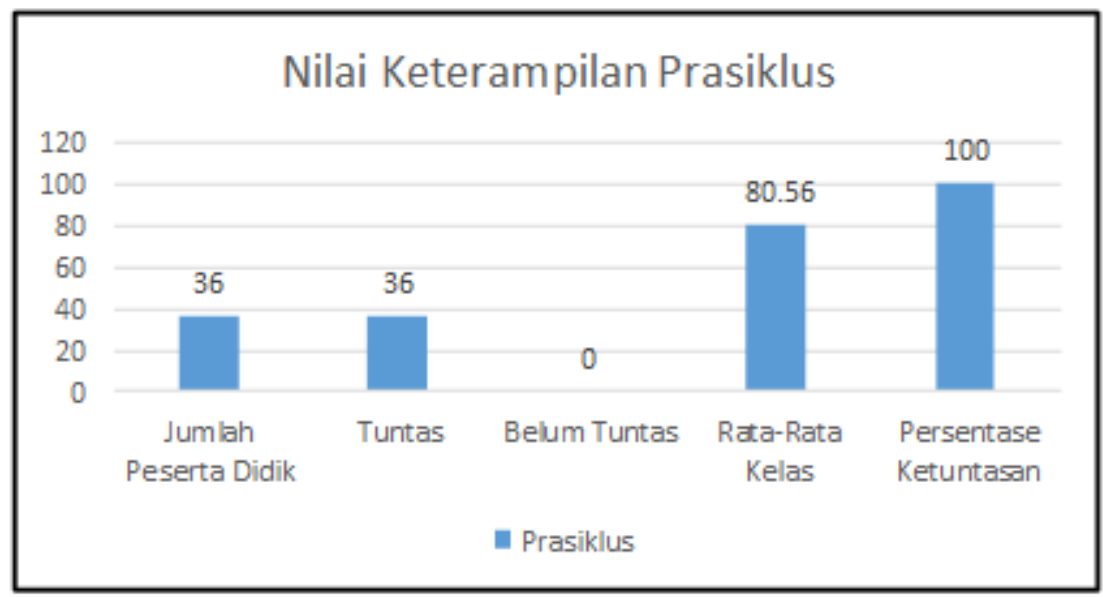

Gambar 2. Nilai Keterampilan Prasiklus

Berdasarkan perolehan nilai prasiklus dapat disimpulkan bahwa penggunaan metode konvensional yaitu ceramah dan tanya jawab mengakibatkan peserta didik kurang memahami materi secara keseluruhan. Rencana penelitian selanjutnya adalah menerapkan pembelajaran Scientific Apprroach Model Pembelajaran Abad ke-21 Metode Blended Learning. Adapun yang akan penulis lakukan antara lain adalah

1. Menggunakan Scientific Apprroach Model Pembelajaran Abad ke-21 Metode Blended Learning yang diterapkan kepada peserta didik untuk meningkatkan hasil belajarnya.

2. Mengadakan refleksi pada setiap pertemuan untuk mengukur keberhasilan pembelajaran setiap pertemuan.

\section{Deskripsi Siklus I}

\section{Perencanaan}

Kegiatan siklus I akan dilaksanakan empat pertemuan. Pertemuan ke-1, ke-2, ke-3 dan penilaian (tes) siklus I pada pertemuan ke-4. Sebelum melakukan tindakan, penulis terlebih dahulu mempersiapkan segala sesuatu yang diperlukan dalam penelitian ini, diantaranya adalah: Silabus Pembelajaran dan Rencana Pelaksanaan Pembelajaran (RPP) yang disesuaikan dengan rencana Tindakan yaitu Persiapan Perangkat Pembelajaran, Persiapan Instrumen Penelitian.

\section{Pelaksanaan Tindakan}

Pelaksanaan Tindakan dilakukan pada siklus I yang terdiri dari empat pertemuan. Pertemuan 1 dilakukan pada hari Jum'at tanggal 27 Agustus 2021, pertemuan 2 pada hari Jum'at tanggal 3 September 2021, pertemuan 3 pada hari Jum'at tanggal 10 September 2021 dan pertemuan 4, evaluasi, pada hari Jum'at tanggal 17 September 2021. Adapun rangkaian kegiatan pelaksanaan 
pembelajaran siklus I pada materi Expressing Giving Compliment and Cogratulation dengan metode Blended learning sebagai terlampir pada lampiran 03.

\section{Observasi}

Nilai pengetahuan yang diperoleh peserta didik setelah penilaian siklus I dapat dilihat pada tabel berikut:

Tabel 3. Hasil Pengolahan Perolehan Nilai Pengetahuan Siklus I

\begin{tabular}{|c|l|c|c|}
\hline \multirow{2}{*}{ No } & \multirow{2}{*}{ Uraian } & \multicolumn{2}{c|}{ Frekuensi } \\
\cline { 3 - 4 } & & Prasiklus & Siklus I \\
\hline 1 & Jumlah Peserta Didik & 36 & 36 \\
\hline 2 & Peserta didik tuntas & 0 & 15 \\
\hline 3 & Peserta didik tidak tuntas & 36 & 21 \\
\hline 4 & Nilai rata-rata kelas & 49,31 & 73,43 \\
\hline 5 & Persentase Ketuntasan & 0 & 41,67 \\
\hline
\end{tabular}

Berdasarkan hasil pengolahan nilai pengetahuan yang diperoleh peserta didik pada siklus I terlihat bahwa, dari 36 orang peserta didik ada 21 orang atau 58,33\% yang tidak tuntas, sedangkan 15 peserta didik atau $41,67 \%$ telah tuntas, dan nilai rata-rata kelas 73,43 . Hasil pengolahan nilai pengetahuan ini dapat dilihat pada grafik berikut:

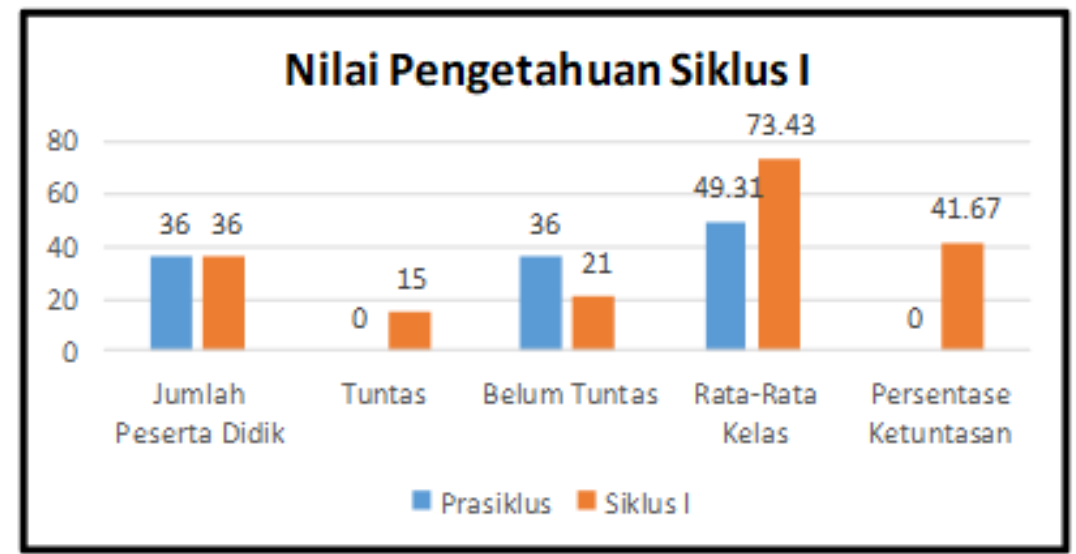

Gambar 3. Nilai Pengetahuan Siklus I

Nilai keterampilan yang diperoleh peserta didik setelah penilaian siklus I dapat dilihat pada lampiran. Sama halnya dengan di prasiklus, nilai keterampilan siklus I, dari 36 orang peserta didik tuntas $100 \%$. Nilai rata-rata ketuntasannya adalah 84,51 . Hal ini menyebabkan kenaikan dari prasiklus ke siklus I sebanyak 4,90\%. Rekapitulasi nilai keterampilan siklus I dapat dilihat pada tabel berikut:

Tabel 4. Hasil Pengolahan Perolehan Nilai Keterampilan Siklus I

\begin{tabular}{|l|l|l|l|}
\hline \multirow{2}{*}{ No } & \multirow{2}{*}{ Uraian } & Frekuensi & \\
\cline { 3 - 4 } & & Prasiklus & Siklus I \\
\hline 1 & Jumlah Peserta Didik & 36 & 36 \\
\hline 2 & Peserta didik tuntas & 36 & 36 \\
\hline 3 & Peserta didik tidak tuntas & 0 & 0 \\
\hline 4 & Nilai rata-rata kelas & 80,56 & 84,51 \\
\hline 5 & Persentase ketuntasan & 100 & 100 \\
\hline
\end{tabular}


Peningkatan Hasil Pembelajaran HOTs pada Mata Pelajaran Bahasa Inggris Materi Expressing Giving Compliment and Congratulation Melalui Scientific Approach Model Pembelajaran Abad Ke-21 Metode Blended Learning Peserta Didik Kelas X.IPK.3 MAN 2 Kota Payakumbuh Semester Ganjil Tahun Pelajaran 2021/2022, Josmartin Peto

Berdasarkan tabel di atas terlihat bahwa, semua peserta didik tuntas, dengan nilai rata-rata

kelas 84,51 . Hasil pengolahan nilai keterampilan ini dapat dilihat pada grafik berikut.

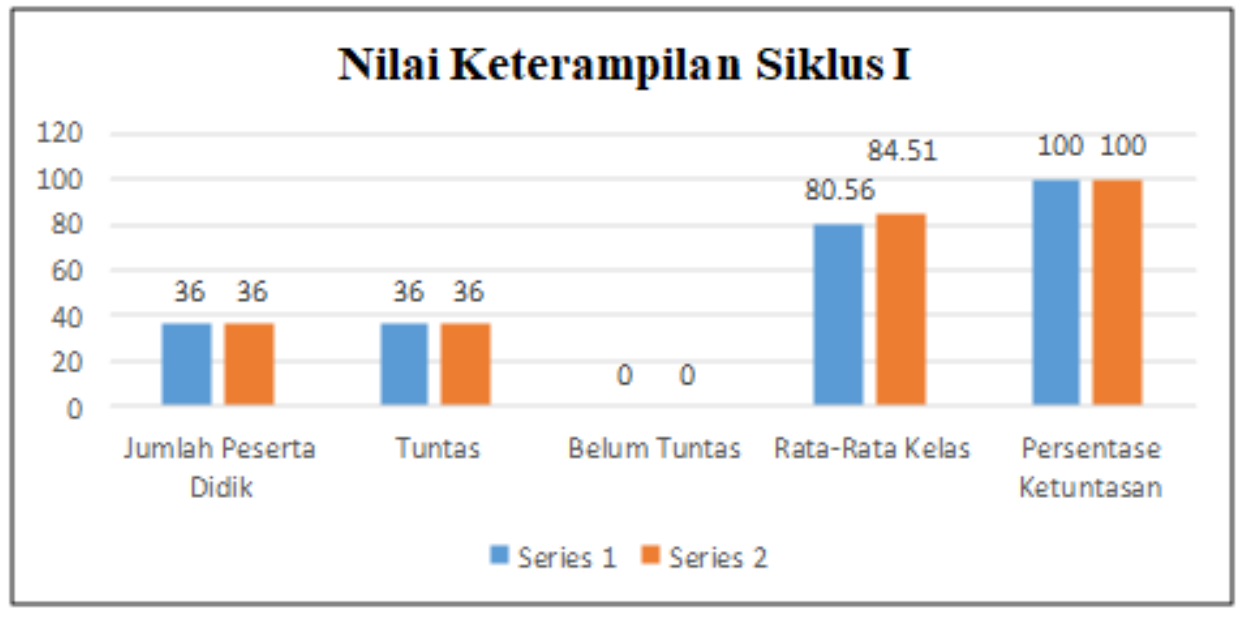

Gambar 4. Nilai Keterampilan Sikus I

Berdasarkan perolehan nilai prasiklus dan siklus I menunjukkan adanya peningkatan hasil belajar peserta didik. Untuk nilai pengetahuan persentase peserta didik yang tuntas meningkat dari $0 \%$ pada prasiklus menjadi 41,67\% pada siklus I. Untuk nilai keterampilan persentase peserta didik yang tuntas $100 \%$ pada prasiklus tetap $100 \%$ pada siklus I. Perolehan hasil siklus I menunjukkan bahwa implementasi pembelajaran metode Blended learning cukup efektif untuk meningkatkan hasil belajar mata pelajaran Bahasa Inggris. Ketuntasan nilai pengetahuan di siklus I belum signifikan, masih perlu ditingkatkan pada siklus II.

\section{Refleksi}

Kegiatan pada siklus I menunjukkan tidak ada permasalahan dalam perumusan Rencana Pelaksanaan Pembelajaran (RPP). Jadwal pertemuan telah sesuai dengan kebutuhan pelaksanaan pembelajaran. Sedangkan pada tahap pelaksanaan Tindakan terdapat beberapa kekurangan. Kekurangan-kekurangan pada siklus I disebabkan karena adanya kendala-kendala saat melakukan Tindakan. Kendala yang peneliti hadapi dan rencana perbaikan siklus II dapat dilihat pada table berikut:

Tabel 5. Kendala Tindakan Siklus I dan Rencana Perbaikan Siklus II

\begin{tabular}{|c|l|l|}
\hline No & \multicolumn{1}{|c|}{ Kendala Siklus I } & \multicolumn{1}{c|}{ Rencana Perbaikan Siklus II } \\
\hline 1. & $\begin{array}{l}\text { Kondisi peserta didik belum terkendali } \\
\text { saat mengerjakan LKPD }\end{array}$ & $\begin{array}{l}\text { Guru merancang lembar observasi } \\
\text { kelompok untuk memotivasi peserta didik } \\
\text { agar dapat mengerjakan LKPD dengan } \\
\text { baik. }\end{array}$ \\
\hline 2. & $\begin{array}{l}\text { Peserta didik belum berani } \\
\text { memberikan pendapat atas kerja } \\
\text { temannya. }\end{array}$ & $\begin{array}{l}\text { Bersama peserta didik guru membahas } \\
\text { hasil pekerjaan peserta didik lainnya dan } \\
\text { meminta mereka memberikan tanggapan. }\end{array}$ \\
\hline 3. & $\begin{array}{l}\text { Sebagian peserta didik kurang disiplin } \\
\text { mengikuti pembelajaran }\end{array}$ & $\begin{array}{l}\text { Guru harus lebih memperhatikan disiplin } \\
\text { peserta didik dalam mengikuti } \\
\text { pembelajaran. }\end{array}$ \\
\hline 4. & Perolehan hasil belajar peserta didik & \begin{tabular}{l} 
Guru memberikan review sebelum peserta \\
\hline
\end{tabular} \\
\hline
\end{tabular}


pada akhir siklus I yang mencapai didik melakukan tes akhir siklus II. KKM masih $41,67 \%$

\section{Deskripsi Siklus II}

\section{Perencanaan}

Pada tahap perencanaan pembelajaran siklus II, Tindakan yang dilakukan hampir sama dengan pembelajaran siklus I. Adapun rancangan Tindakan yang akan penulis lakukan antara lain adalah sebagai berikut: Menyusun rencana pelaksanaan pembelajaran (RPP) tentang Descriptive Text KD 3.3 - 4.3. Membuat tugas peserta didik berupa LKPD. Menyusun kisi-kisi soal tes siklus II. Menyusun soal tes siklus II berupa 10 butir soal pilhan ganda dan 5 butir soal uraian

\section{Tindakan}

Peneliti melaksanakan Tindakan siklus II sesuai dengan RPP II yang telah disusun. Pelaksanaan Tindakan siklus II ini terdiri dari 4 kali pertemuan. Pertemuan 1 dilaksanakan pada hari Jum'an tanggal 24 September 2021, pertemuan 2 dilaksanakan pada hari Jum'at, 1 Oktober 2021, pertemuan 3 dilaksanakan pada hari Jum'at tanggal 15 Oktober 2021 dan pertemuan 4 dilaksanakan pada hari Jum'at tanggal 22 Oktober 2021. Adapun rangkaian kegiatan pelaksanaan pembelajaran siklus II pada materi Descriptive Text dengan Scientific Approach Model Pembelajaran Abad ke-21 Metode Blended learning adalah sebagaimana RPP terlampir.

\section{Pengamatan}

Setelah Tindakan dilakukan sebanyak tiga kali pertemuan dan dilakukan penilaian tertulis pada akhir siklus II, diperoleh hasil belajar peserta didik sebagai berikut: Nilai pengetahuan yang diperoleh peserta didik setelah penilaian siklus II dapat dilihat pada lampiran berikut.

Tabel 6. Hasil Pengolahan Nilai Pengetahuan Siklus II

\begin{tabular}{|c|l|c|c|c|}
\hline \multirow{2}{*}{ No } & \multirow{2}{*}{ Uraian } & \multicolumn{3}{|c|}{ Frekuensi } \\
\cline { 3 - 5 } & & Prasiklus & Siklus I & Siklus II \\
\hline 1 & Jumlah Peserta Didik & 36 & 36 & 36 \\
\hline 2 & Peserta didik tuntas & 0 & 15 & 28 \\
\hline 3 & Peserta didik tidak tuntas & 36 & 21 & 8 \\
\hline 4 & Nilai rata-rata kelas & 49,31 & 73,43 & 77,70 \\
\hline 5 & Persentase ketuntasan & 0 & 41,67 & 77,78 \\
\hline
\end{tabular}

Berdasarkan perolehan nilai pengetahuan siklus II pada table di atas terlihat bahwa dari 36 peserta didik yang mengikuti ujian, 9 peserta didik atau 22,22\% tidak tuntas dan 28 peserta didik atau $77,70 \%$ tuntas, dan nilai rata-rata kelas 77,78 . Hasil pengolahan nilai di atas dapat dilihat pada grafik berikut. 
Peningkatan Hasil Pembelajaran HOTs pada Mata Pelajaran Bahasa Inggris Materi Expressing Giving Compliment and Congratulation Melalui Scientific Approach Model Pembelajaran Abad Ke-21 Metode Blended Learning Peserta Didik Kelas X.IPK.3 MAN 2 Kota Payakumbuh Semester Ganjil Tahun Pelajaran 2021/2022, Josmartin Peto

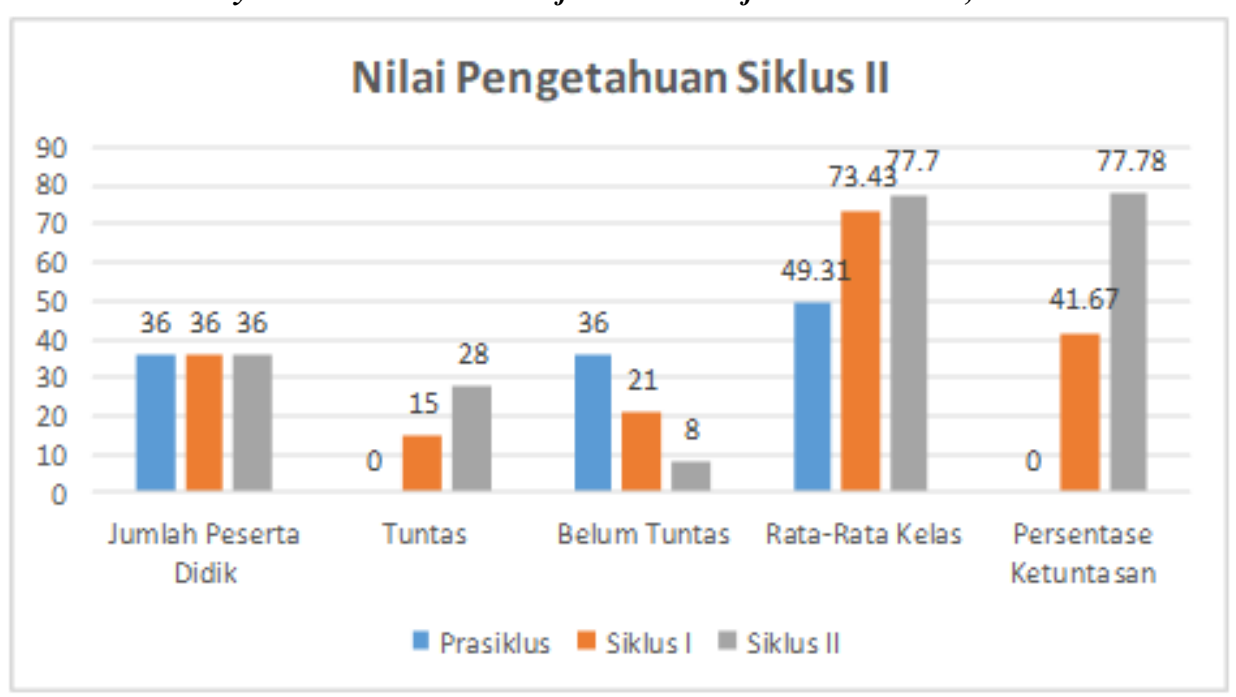

Gambar 5. Nilai Pengetahuan Siklus II

Selanjutnya rekapitulasi nilai keterampilan pada siklus II dapat dilihat pada tabel berikut:

Tabel 7. Hasil Pengolahan Nilai Keterampilan Siklus II

\begin{tabular}{|c|l|c|c|c|}
\hline \multirow{2}{*}{ No } & \multirow{2}{*}{ Uraian } & \multicolumn{3}{|c|}{ Frekuensi } \\
\cline { 3 - 5 } & & Prasiklus & Siklus I & Siklus II \\
\hline 1 & Peserta & 36 & 36 & 36 \\
\hline 2 & Peserta didik tuntas & 0 & 36 & 36 \\
\hline 3 & Peserta didik tidak tuntas & 80,56 & 0 & 0 \\
\hline 4 & Nilai rata-rata kelas & 100 & 100 & 100 \\
\hline 5 & Persentase ketuntasan & \multicolumn{3}{|c|}{} \\
\hline
\end{tabular}

Berdasarkan tabel perolehan nilai keterampilan siklus II di atas terlihat bahwa dari semua peserta didik tuntas atau 100\%. Hasil pengolahan nilai diatas dapat dilihat pada grafik berikut:

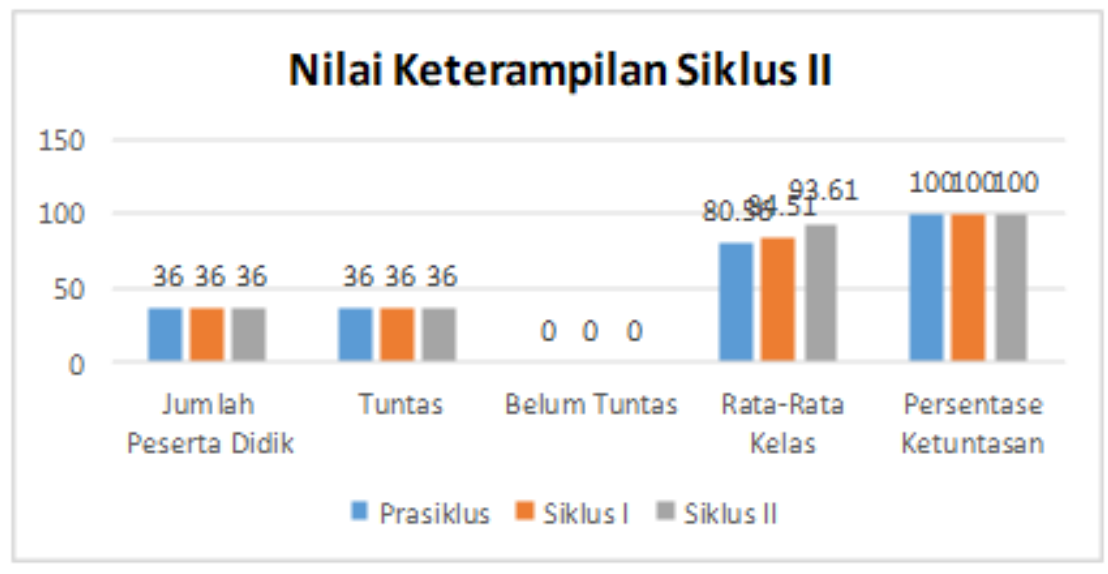

Gambar 6. Nilai Keterampilan Siklus II

Perolehan nilai siklus I ke siklus II menunjukkan adanya peningkatan hasil belajar peserta didik. Persentase nilai pengetahuan peserta didik yang tuntas meningkat dari $41,67 \%$ pada siklus I menjadi $86,47 \%$ dengan nilai rata-rata 77,70 pada siklus II. Namun kenaikan ini belum signifikan, 
masih dalam kategori $\mathrm{C}$, sementara persentase nilai keterampilan peserta didik pada siklus I tuntas $100 \%$ dengan nilai rata-rata 84,51. Pada siklus II ketuntasan belajar keterampilan juga 100\% dengan nilai rata-rata 93,61 meningkat menjadi 10,76\%. Rata-rata kelas pada siklus ini naik sangat signifikan, kategori A.

\section{Refleksi}

Setelah siklus II berakhir penulis melakukan refleksi untuk mengidentifiksi permasalahan yang ada. Adapun hasil refleksi siklus II adalah hasil belajar untuk nilai pengetahuan yang diperoleh peserta didik masih mendapat nilai rata-rata pada siklus II dengan kategori C. Hal ini disebabkan karena masih kurangnya kesadaran peserta didik mengikuti pembelajaran. Artinya peserta didik belum tuntas secara individu maupun klasikal. Sedangkan untuk nilai keterampilan mendapat nilai yang cukup signifikan, kategori A.

\section{KESIMPULAN}

Hasil yang diperoleh pada prasiklus, siklus I dan siklus II menunjukkan adanya peningkatan.

1. Nilai pengetahuan, Nilai rata-rata kelas pengetahuan peserta didik meningkat dari 49,31 dengan ketuntasan $0 \%$ pada prasiklus menjadi 73,43 dengan ketuntasan $(41,67 \%)$ pada siklus I dan menjadi 77,70 (77,78\%) pada siklus II. Di sini dapat dilihat persentase peserta didik yang tidak tuntas menjadi menurun.

2. Nilai keterampilan, Nilai rata-rata keterampilan juga meningkat dari 80,56 pada prasiklus menjadi 84,51 (4,90\%) pada siklus I, dan menjadi 93,61 (10,77\%) pada siklus II. Pada setiap tindakan, seluruh peserta didik tuntas $100 \%$. Berdasarkan hasil penilaian siklus II tersebut dapat diartikan bahwa implementasi Scientific Apprroach Model Pembelajaran Abad ke-21 Metode Blended Learning dapat meningkatkan hasil belajar tingkat tinggi Bahasa Inggris peserta didik, walaupun peningkatannya belum sesuai dengan harapan, namun ini cukup efektif dalam pembelajaran Bahasa Inggris.

\section{REFERENSI}

Arikunto, Suharsini. 2006. Prosedur Penelitian Suatu Pendekatan Praktik, Jakarta: Rineka Cipta Bonk and Graham (2006). The Handbook of Blended Learning. USA :Pfeiffer.

Budiharti, Rini, 2015. Penggunaan Blended Learning dengan Media Moodle untuk Meningkatkan Kemampuan Kognitif Siswa SMP Fakultas Keguruan Ilmu Pendidikan Universitas Negeri Surakarta: Unpublished Thesis

Djamarah, Syaiful Bahri. 2002. Strategi Belajar Mengajar, Jakarta: Rineka Putra

Djamarah, Syaiful Bahri dan Aswan Zain. 2006. Strategi Belajar Mengajar. Jakarta: Rineka Cipta

Drost, J. (1999). Proses Pembelajaran Sebagai Proses Pendidikan. Jakarta: PT Gramedia

Dwiyogo, Wasis D. 2018. Pembelajaran Bauran (Blended Learning). Jakarta: Prestasi Pustaka Jaya. 
Peningkatan Hasil Pembelajaran HOTs pada Mata Pelajaran Bahasa Inggris Materi Expressing Giving Compliment and Congratulation Melalui Scientific Approach Model Pembelajaran Abad Ke-21 Metode Blended Learning Peserta Didik Kelas X.IPK.3 MAN 2 Kota Payakumbuh Semester Ganjil Tahun Pelajaran 2021/2022, Josmartin Peto Elenena Mosa (2006). A blended E-Learning Models, Italia: Italian Journal of Education Technology 17(3)

Hamalik, Oemar. 2009. Proses Belajar Mengajar. Bandung: Bumi Aksara.

Haryanto. 2006. Perencanaan Pengajaran, Jakarta: Rineka Cipta.

Harys Imanulloh (2020) https://www.tripven.com/pembelajaran-abad-21/

Hidayati, Nidia. 2021. Meningkatkan Aktivitas dan Hasil Belajar Siswa Melalui Model Blended Learning Berbantuan Media Bongkar Pasang pada Materi Tatanama Senyawa di SMA Negeri 1 Bandar Baru, Fakultas Tarbiyah dan Keguruan Universitas Islam Negeri Ar-Raniry Banda Aceh: Unpublished Thesis.

Isnadi, Rahmat (2020) https: //www. necerz. Com /2020/ 06/ pengertian-jenis- dan-fungsiexpression.html

Khan, B. (2005). Maraging E-Learning Strategis: Design, Delivery, Implementationand Education. USA: Idea Grou, Inc

Kumalasari Kokom. (2010). Pembelajaran Kontekstual Konsep dan Aplikasi. Bandung: PT. Refika Aditama.

Kurikulum 2013 Perubahan KD Permen 37-2018 menjadi KD Kepbalitbangbuk 018-2020

Kurniati, Dian. 2016. Kemampuan Berpikir Tingkat Tinggi Siswa SMP Di Kabupaten Jember Dalam Menyelesaikan Soal Berstandar PISA. Penelitian dan Evaluasi Pendidikan 20(2), 142-155.

Muhson, Nurul 2019, Penerapan Blended Learning dalam Meningkatkan Hasil Belajar PAI Materi Sejarah Bani Umaiyah Kelas VIII SMPN 3 Pontianak, IKIP PGRI Pontianak: Unpublished Thesis

Noirid, S., 2007. "E-learning Models: A Review of Literature". The 1st International Conference on Educational Reform November 9-11, 2007. Bangkok, s.n. Analysis with Traditional and Fully Online Graduate Course, International Review of Research in Open and Distance Learning, Vol 5, dari http: //www. rrodl. org/index. php. irrodl /article /viewfile/192/795

Nurdin, Syafrudin. 2002. Guru Profesional dan Implementasi Kurikulum. Jakarta: PT Intermasa Roshonah, Adiyati Fathu, 2020. Penerapan Model Blended Learning untuk Meningkatkan Prestasi Belajar Matematika di SDN Pisangan 01, Universitas Muhammadiyah Jakarta: Unpublished Thesis

Rovai, AP, Jordan, HM. (2004). Blended Learning and Sense of Community: A Comparative Roestiyah, N.K. 1998. Strategi Belajar Mengajar. Jakarta: PT Rhineka Cipta Rusman. 2015. Pembelajaran Tematik Terpadu, Teori Praktik dan Penilaian. Grafindo: Jakarta Sanjaya, Wina. 2007. Strategi Pembelajaran Berorientasi Standar Proses Pendidikan. Jakarta: Kencana Prenada Media. 
Saputra, Hatta. 2016. Pengembangan Mutu Pendidikan Menuju Era Global. Penguatan Mutu Pembelajaran dengan Penerapan HOTS (High Order Thinking Skills). Bandung: Smile's Publishing

Sardiman AM. (2011). Interaksi dan Motivasi Belajar Mengajar. (Jakarta: Raja Grafindo Persada.

Slamet. 1996. Belajar dan Faktor-Faktor yang Mempengaruhinya. Jakarta: Rineka Cipta.

Smaldino, Sharon E, dkk (2007). Instructional Technology and Media for Learning Ninth Edition.

New Jersey Colombus, Ohio: Pearson Merril Prentise Hall.

Smaldino, S., Lowther, D. \& Russel, J., 2008. Instructional Technology and Media for Learning.

Ninth Edition penyunt. Upper Saddle River, New Jersey, USA: Perason Prentice Hall, Pearson Education, Inc

Sudjana, Nana. (1989). Dasar-dasar Proses Belajar Mengajar. Bandung: Sinar Baru Algasindo.

Syarif, Izzudin. 2012. Pengaruh Model Blended Learning terhadap Motivasi dan Prestasi Belajar

Siswa SMK. Jurnal Pendidikan, (online), 2 (2: 234-249 tersedia: http://journal.uny.ac.id diunduh 20 Juni 2021

Thorne. (2003). European Jurnal Blended Learning, http://www.eurod/.org/?tag=34issue7, volume 2003 March 2003 Furchan

Valiathan P. (2002). Blended Learning Models. Learning Circuit 3(8). PP. 50-59

W.J.S, Poerwadarminta. 1996. Kamus Umum Bahasa Indonesia. Jakarta: Balai Pustaka.

Watson, J., 2008. Blended Learning: Convergence between Online and Face-to-Face Education. USA:

North American Council for Online Learning

Widodo, T \& Kadarwati, S. 2013. High Order Thinking Berbasis Pemecahan Masalah Untuk

Meningkatkan Hasil Belajar Berorientasi Pembentukan Karakter Siswa. Cakrawala Pendidikan 32(1), 161-171.

Wonggo, Djafar 2021, Penerapan Model Pembelajaran Blended Learning untuk Meningkatkan Hasil

Belajar Siswa Kelas X TKJ SMK Negeri 2 Maluku Tenggara, Jurusan Pendidikan Teknologi

Informasi dan Komunikasi, Fakultas Teknik, Universitas Negeri Manado: Unpublished Thesis

Zhao. (2008). An Examination of Students Perception of Blenden e-Learning in Chinese Higher Education. Technologi for E-learning and Dugital Entertainment, 162-170

Undang-undang Nomor 20 Tahun 2003 Tentang Sistem Pendidikan Nasional.

Peraturan Pemerintah nomor 21 tahun 2008 tentang penyelenggaraan Penanggulangan Bencana.

Peraturan Pemerintah Nomor 17 Tahun 2010 tentang Pengelolaan dan Penyelenggaraan Pendidikan sebagaimana telah diubah dengan PeraturanPemerintah Nomor 66 Tahun 2010 tentang Perubahan atas Peraturan Pemerintah Nomor 17 Tahun 2010 tentang Pengelolaan dan Penyelenggaraan Pendidikan; dan Peraturan Menteri Pendidikan dan Kebudayaan Nomor 33 Tahun 2019 tentang Satuan Pendidikan Aman Bencana.

Keputusan Presiden Republik Indonesia Nomor 11 Tahun 2020 tentang Penetapan Kedaruratan Kesehatan Masyarakat Corona Virus Disease 2019 (Covid-19). 
Peningkatan Hasil Pembelajaran HOTs pada Mata Pelajaran Bahasa Inggris Materi Expressing Giving Compliment and Congratulation Melalui Scientific Approach Model Pembelajaran Abad Ke-21 Metode Blended Learning Peserta Didik Kelas X.IPK.3 MAN 2 Kota Payakumbuh Semester Ganjil Tahun Pelajaran 2021/2022, Josmartin Peto

Surat Edaran Mentri Pendidikan dan Kebudayaan Republik Indonesia Nomor 4 Tahun 2020 tentang

Pelaksanaan Kebijakan Pendidikan Dalam Masa Darurat Penyebaran Corona Virus Disease 2019 (Covid-19).

Surat Edaran Menteri Pendidikan dan Kebudayaan Nomor 15 Tahun 2020 tentang Pedoman Penyelenggaraan Belajar dari rumah dalam Masa Darurat Penyebaran Corona Virus Disease (Covid-19).

http://www.bakharuddin.net/2013/09/pendekatan-scientific-untuk-penerapan.html http://www.wartamadrasahku.com/2016/05/metode-pembelajaran-bahasa-inggris.html https://suhermanmaman.wordpress.com/2013/11/03/scientific-approach-pedekatan-ilmiah-dalampendidikan/

https://www. eurekapendidikan. com/2015/09 /hakikat-scientific- approach- atau.html Scientific approach

https://www.sederet.com/tutorial/apa-itu-expression-of-compliment/ 